\title{
Characterization of Proinsulin-Insulin
}

\section{Intermediates in Human Plasma}

\author{
Christoph de HaËn, Sally A. Little, James M. May, and Robert H. Williams, \\ Division of Metabolism, Endocrinology, and Gerontology, Department of \\ Medicine, University of Washington, Seattle, Washington 98195
}

A B S T RACT This work addressed the problem of heterogeneity of immunoreactive insulin (IRI) in human plasma. Subjects with normal glucose tolerance were given $75 \mathrm{~g}$ of an oral glucose solution, followed in $30 \mathrm{~min}$ by an intravenous infusion of $30 \mathrm{~g}$ of arginine over $30 \mathrm{~min}$. At the end of the infusion blood was withdrawn for analysis. IRI was extracted from plasma of individual subjects by immunosorbent columns and was fractionated by gel filtration, disc gel electrophoresis and isoelectric focusing. Human IRI components were identified by molecular size, immunoreactivity with a human proinsulin antibody, sensitivity to trypsin, and by comparison of electrophoretic mobility and isoelectric point with porcine pancreatic products, after suitable correction for electric charge and molecular weight differences.

The pattern of IRI heterogeneity was the same among six healthy subjects. Heterogeneity of proinsulin-size IRI in circulation was more marked than that of insulinsize material. Proinsulin and desdipeptide proinsulin were present in approximately equal amounts accompanied by minor amounts of split proinsulin and monodesamido-desdipeptide proinsulin. Insulin-size IRI contained over $80 \%$ insulin. Minor amounts of monodesamidoinsulin and diarginylinsulin were observed in some cases.

The types of IRI components observed in plasma are evidence in support of a physiologic role of trypsinand carboxypeptidase B-like enzymes in the conversion of proinsulin to insulin. Moreover, this study provides a base line for investigation of abnormalities in proinsulin-to-insulin conversion that may be associated with certain pathologic states.

This work was presented in part at the Annual Meetings of the American Society of Biological Chemists in San Francisco, Calif., June 1976 (Abstr. 1371) and the Annual Meeting of the American Diabetes Association in St. Louis, Mo., June 1977 (Abstr. 93).

Received for publication 12 January 1.978 and in revised form 12 May 1978.

\section{INTRODUCTION}

Insulin biosynthesis involves as last step(s) the proteolytic conversion of a single chain precursor proinsulin to the double chain product of insulin (1-3). In the process a certain number of amino acid residues, e.g. 33 in the case of porcine (4), and 35 in the case of human proinsulin $(5,6)$, are excised from the middle of the chain of proinsulin (Fig. 1). The conversion of proinsulin takes place inside the secretory granule of the pancreatic $\beta$-cell in the course of its maturation (7-9). Proinsulin, insulin, and a variety of derivatives obtained by proteolytic modification thereof have been isolated from pancreas homogenates and their chemical, biological, and immunological properties have been characterized (10-16). Also, the structure of the peptide excised from proinsulin during the conversion to insulin in the pancreas has been elucidated from a variety of species $(4,5,9,17)$.

The same derivatives of proinsulin and insulin that were isolated from homogenized pancreas could also be obtained by in vitro enzymatic digestion of proinsulin or insulin with exocrine pancreatic trypsin, chymotrypsin, and carboxypeptidase B, alone or in combination (18). From these observations it was inferred that physiologic conversion of proinsulin to insulin involved the stepwise action of enzymes with similar specificities. This was strongly supported by studies of the conversion of selectively prelabeled proinsulin to insulin in a crude secretion granule fraction isolated from rat islets of Langerhans (9).

Roth et al. (19) and Rubenstein et al. (20) first described a blood plasma component with a molecular weight higher than insulin that showed insulin immunoreactivity. This component became commonly thought of as proinsulin. Later, Lazarus et al. $(21,22)$ and Gutman et al. (23) pioneered the characterization of circulating insulin immunoreactive material by disc gel electrophoresis, and found, that the so-called proinsulin fraction was heterogeneous.

After improving and extending a number of tech- 


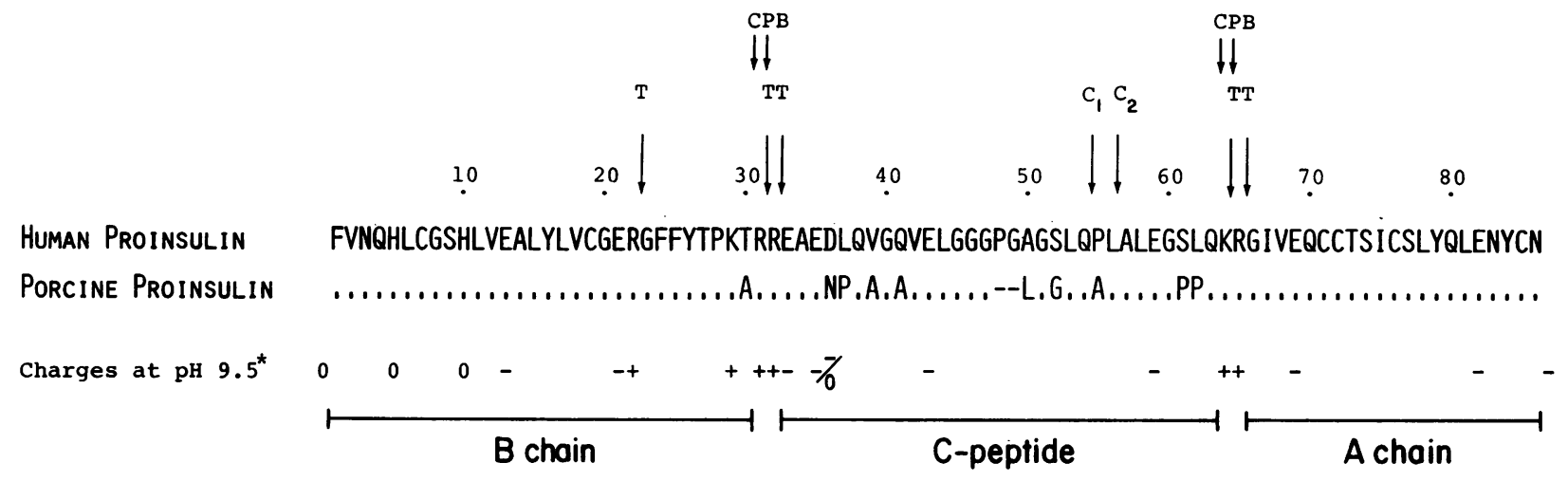

FIGURE 1 Amino acid sequences of human and porcine proinsulin, and the assignment of electric charges to ionizable residues under the conditions of disc gel electrophoresis at pH 9.5. $\left({ }^{*}\right)$ Although there are probably fractional charges on Tyr and Lys at this $\mathrm{pH}$, their inclusion in fitting Eq. 1 did neither improve the fit nor affect the conclusions. The one-letter notation for amino acid sequences is that adopted by the IUPAC-IUB ${ }^{1}$ (1968. J. Biol. Chem. 243: 3557-3559). Points indicate residues identical to those found in human proinsulin. Dashes indicate a deletion of residues in porcine proinsulin. Arrows indicate peptide cleavage sites observed during proinsulin-to-insulin conversion. $T$ designates sites of tryptic cleavage, CPB sites of subsequent removal of basic residues by enzymes with carboxypeptidase B-like specificity, $C_{1}$ indicates a site susceptible to chymotrypsin in rat proinsulin (46), and $C_{2}$ the cleavage site observed in porcine proinsulin $(13,14)$.

niques for identification, we investigated the presence and identity of proinsulin-insulin intermediates, as well as partial degradation products of insulin in plasma of individual human subjects. The results provide evidence that the stepwise proinsulin-to-insulin conversion by enzymes with tryptic and carboxypeptidase B-like specificities is physiologic. The relative quantities of such intermediates gives some rough estimate of the extent to which the $\beta$-cell is capable of completing conversion in a stimulated state. Moreover, this work provides a base line for investigations of abnormal products or abnormal amounts of normal products in certain forms of diabetes mellitus and other pathologic states where incomplete conversion of proinsulin to insulin is suspected.

\section{METHODS}

Materials. Porcine insulin (Sigma Chemical Co., St. Louis, Mo.) was purified to electrophoretic homogeneity according to Chance (14). Porcine desoctapeptide insulin ([desoctapeptide (23-30)]-insulin) was prepared according to Young and Carpenter (24). Biotinylinsulins were prepared by May et al. (25).

The following porcine products were gifts of Dr. Ronald E. Chance, Eli Lilly \& Co. Research Laboratories, Indianapolis, Ind.: proinsulin, lot 615-1112 B-278; [seco-56/57]-proinsulin-(1-56/57-86)-tetrapentaconta/triacontapeptide, ${ }^{1}$ (split

1 The nomenclature follows the rules set forth by the International Union of Biochemistry and the Union of Pure and Applied Chemistry (IUPAC-IUB) Commission on Biochemical Nomenclature (1967) J. Biol. Chem. 242: 555557. The use of "seco" followed by the position numbers proinsulin) lot 615-1070B-30-2; [desdipeptide-(64-65), seco 63/66]proinsulin-(1-63/66-86)-henihexaconta/henicosa peptide, (desdipeptide proinsulin) lots 615-1070B-138-1 and 615-1112B-32; [desnonapeptide-(57-65); seco-56/66]proinsulin-(1-56/66-86)-tetrapentaconta/henicosa peptide, (desnonapeptide proinsulin) lots $615-1039 \mathrm{~B}-256-3$ and 6151112B-31; insulin-30-yl-arginylarginine, (diarginylinsulin) lot 615-D63-49; insulin-30-yl-arginine, (monoarginylinsulin) lot 615-D63-192-2; and monodesamidoinsulin, lot 615-1082B248 , a product likely to be deamidated primarily at asparagine 86 (26). We also obtained two preparations of crude pancreatic human proinsulin (lots 615-1054 B-195-A and 615-1054 B-261-5), prepared by classical acid ethanol extraction, gel filtration and crystallization, from which proinsulin was further purified by preparative disc gel electrophoresis at $\mathrm{pH} 9.5$.

Antisera against electrophoretically pure porcine insulin were induced in guinea pigs according to Yalow and Berson $(27,28)$. A guinea pig antiserum against a mixture of human proinsulin derivatives was kindly provided by Dr. Arthur $\mathrm{H}$. Rubenstein, University of Chicago (Antiserum Ab-G [29]). Cellulose powder MN 300 for thin-layer chromatography (Brinkmann Instruments, Inc., Westbury, N. Y.) was used in the radioimmunoassay of insulin.

Other supplies were obtained as follows: activated $\mathrm{CH}$ Sepharose 4B (lot 5085), Pharmacia Fine Chemicals, Inc., Uppsala, Sweden; Affi-Gel 10 (lot 13882-3) Bio-Rad Laboratories, Richmond, Calif.; heparin as a sodium heparin injection preparation U. S. Pharmacopeia (Panheprin), Abbott Diagnostics, North Chicago, Ill.; crude soybean trypsin inhibitor type II-S, Sigma Chemical Co.; bovine serum albumin Cohn

to indicate the cleavage of internal peptide bonds is analogous to its use in organic chemical nomenclature, and was suggested by Dr. Robert Schwyzer. Amino acid position numbers for both human and porcine peptides are those of human proinsulin in Fig. 1. Traditional abbreviated nomenclature given in parenthesis, is used throughout the paper. 
fraction V (BSA), ${ }^{2}$ Miles Laboratories, Inc., Kankakee, Ill. (checked for absence of immunoreactive insulin (IRI) and interference with the immunoassay); bovine trypsin treated with L-(1-tosylamido-2-phenyl)ethyl chloromethylketone Worthington Biochemical Corp., Freehold, N. J.; African lungfish trypsin $A_{1}$, prepared by the method of de Haën et al. (30); merthiolate R (1:1000) stainless, Eli Lilly \& Co.; Na ${ }^{125}$ I protein iodination grade, New England Nuclear, Boston, Mass.; Ampholine pH 5-7, LKB-Produktor, Bromma, Sweden; BioLyte pH 4-6 and pH 6-8, Bio-Rad Laboratories; oral glucose (Glucola, $75 \mathrm{~g}$ in $207 \mathrm{ml}$ ), Ames Co., Div. of Miles Lab., Inc., Elkhart, Ind., sterile arginine for intravenous infusion (100 $\mathrm{g} /$ liter arginine $\mathrm{HCl}$ in water), prepared by the University of Washington Pharmacy; ultrapure urea, Schwarz/Mann Div., Becton, Dickinson \& Co., Orangeburg, N. Y. Before use, cyanate was removed from all urea solutions by passage through a column of mixed bed ion exchange resin AGMI615 (J. T. Baker Chemical Co., Phillipsburg, N. J.).

Human subjects. Subjects were selected on the basis of the following criteria: age, 30-55-yr-old; body weight, 100-120\% of expected lean body weight for height and age (Metropolitan Life Insurance Tables); normal oral glucose tolerance test; normal basal insulin levels and good general health; no known family history of diabetes or of myocardial infarctions before the age of 50.

Collection of blood specimens. Human subjects having followed a diet providing at least $300 \mathrm{~g} /$ day of carbohydrate for a minimum of 2 days arrived at the Clinical Research Center, University of Washington, after an overnight fast. A 19-gauge scalp vein needle was inserted into an antecubital vein and maintained with a slow saline infusion. After a 10-15-min rest, a 5-ml fasting blood sample was withdrawn from the intravenous line for serum glucose determination and analysis of total serum IRI. Each subject then consumed $75 \mathrm{~g}$ of glucose in solution. After $30 \mathrm{~min}$ another $5 \mathrm{ml}$ blood sample was taken for serum glucose and IRI determinations. This was followed by a 30-min infusion of an arginine solution (30 $\mathrm{g}$ in $300 \mathrm{ml}$ of water) through the intravenous line using an infusion pump. Then $240 \mathrm{ml}$ of blood was withdrawn over a period of $10 \mathrm{~min}$, with $50 \mathrm{ml}$ syringes containing $4 \mathrm{ml}$ of an anticoagulant mixture (see below). Portions of the blood $(40 \mathrm{ml})$ were immediately dispensed into $50 \mathrm{ml}$ plastic centrifuge tubes. A final specimen $(5 \mathrm{ml})$ was then taken for serum glucose and total IRI determination. No significant side effects were encountered.

Anticoagulant mixture. The activation of the presently recognized blood clotting enzymes was inhibited by a modified anticoagulant mixture originally described by Fujikawa et al. (31). Table I gives the composition of this mixture and the ratio to be used with blood. EDTA and $o$-phenanthroline were added to inhibit metalloenzymes such as plasma carboxypeptidase B (32), plasma aminopeptidases (33) and metallo-endopeptidases potentially present in plasma or on cell surfaces. $N$-ethylmaleimide was added to inhibit sulfhydryl proteases potentially present and to mask free sulfhydryl groups, such as that of cysteine 34 in albumin (34), to prevent disulfide interchange (35).

Preparation of cell-free plasma. It was necessary to remove platelets as completely as possible to prevent aggregation and clogging of the immunosorbent column. Breakage of cells, on the other hand, had to be minimized, otherwise intracellular proteases could have become active and modified

\footnotetext{
${ }^{2}$ Abbreviations used in this paper: BSA, bovine serum albumin Cohn fraction V; IRI, immunoreactive insulin; pI, isoelectric points.
}

TABLE I

Composition of Anticoagulant Mixture*

\begin{tabular}{llc}
\hline \multicolumn{1}{c}{ Inhibitor } & \multicolumn{1}{c}{$\begin{array}{c}\text { Content per liter } \\
\text { of anticoagulant } \\
\text { mixturet }\end{array}$} & $\begin{array}{c}\text { Final con- } \\
\text { centration } \\
\text { in coagu- } \\
\text { lation } \\
\text { inhibited } \\
\text { blood }\end{array}$ \\
\hline Benzamidine hydrochloride & $100 \mathrm{~g} \S$ & $64 \mathrm{mM}$ \\
Sodium citrate dihydrate & $13.4 \mathrm{~g}$ & $4.5 \mathrm{mM}$ \\
Heparin, $1,000 \mathrm{U} / \mathrm{ml}$ & $17 \mathrm{ml} \cong 100 \mathrm{mg})$ & $1,700 \mathrm{U} / \mathrm{liter}$ \\
Soybean trypsin inhibitor & $100 \mathrm{mg}$ & $10 \mathrm{mg} / \mathrm{liter}$ \\
$o$-Phenanthroline & $19.8 \mathrm{mg}$ & $10 \mu \mathrm{M}$ \\
EDTA Na ${ }_{4} \times 1.5 \mathrm{H}_{2} \mathrm{O}$ & $40.8 \mathrm{mg}$ & $10 \mu \mathrm{M}$ \\
$N$-ethylmaleimide & $1.25 \mathrm{~g}$ & $1 \mathrm{mM}$ \\
\hline
\end{tabular}

* Calcium sequestering agents like citrate or EDTA inhibit coagulation first at the level of Factor IX to IXa conversion, and heparin inhibits first at the level of Factor XI to XIa conversion. Thus, in the presence of only these anticoagulants, coagulation enzymes preceding this step would be active.

\$ 1 vol to be mixed with 9 vol of blood.

$\$$ The 10-fold lower concentration recommended by Fujikawa et al. (31) would probably suffice.

the IRI. The anticoagulated blood was centrifuged at room temperature for $10 \mathrm{~min}$ at $700 \mathrm{~g}$ at one-half the height of the tubes. The supernatant plasma was centrifuged again under the same conditions for $15 \mathrm{~min}$, and was thus freed of erythrocytes and leukocytes. A last centrifugation for 20 min at $2,000 \mathrm{~g}$ removed the platelets. After cooling to $4^{\circ} \mathrm{C}$ for $2 \mathrm{~h}$, the plasma was centrifuged for $2 \mathrm{~h}$ at $10,000 \mathrm{~g}$. $\mathrm{NaN}_{3}$ was added to cell-free plasma to a final concentration of $3 \mathrm{mM}$ and applied to immunosorbent columns.

Preparation of immunosorbent columns. The $\gamma$-globulin fraction of guinea pig antiporcine insulin serum was partially purified by ammonium sulfate fractionation (36) and DEAEcellulose ion exchange chromatography (37). Activated $\mathrm{CH}$ Sepharose 4B (25 g) was coupled, according to the producer's instructions, to $325 \mathrm{mg}$ of partially purified anti-insulin $\gamma$ globulin fraction. Excess coupling sites were reacted with $1 \mathrm{M}$ ethanolamine, $\mathrm{pH} 9$, for $3 \mathrm{~h}$.

The immunosorbent columns were washed extensively with $1 \mathrm{M}$ acetic acid to remove any insulin remaining from original guinea pig serum, equilibrated with and stored in $0.01 \mathrm{M}$ Tris- $\mathrm{HCl}, \mathrm{pH} 8.3$ at $4^{\circ} \mathrm{C}$, containing $3 \mathrm{mM} \mathrm{NaN}_{3}$.

Characterization of immunosorbent columns. The capacities of $1 \mathrm{ml}$ immunosorbent columns were estimated by applying slowly an excess amount of insulin in $5 \mathrm{ml}$ of $0.01 \mathrm{M}$ Tris- $\mathrm{HCl}, \mathrm{pH} 8.3$ at $4^{\circ} \mathrm{C}, 1 \% \mathrm{BSA}$ and measuring the difference between applied and eluted IRI in the sample volume and consecutive washings, consisting of $10 \mathrm{ml}$ of application buffer, $5 \mathrm{ml}$ of $1 \mathrm{M} \mathrm{NaCl}$, and again $10 \mathrm{ml}$ of application buffer. The capacity was found to be $60 \mathrm{mU} / \mathrm{ml}$ of Sepharose. After elution with a total of $15 \mathrm{ml}$ of $1 \mathrm{M}$ acetic acid, evaporation to dryness and dissolution in radioimmunoassay buffer, the recovery for insulin was $89 \%$. The recovery of measured amounts of proinsulin processed similarly was estimated at $84 \%$.

Isolation of human insulin immunoreactive material. The immunosorbent column was equilibrated with $0.01 \mathrm{M}$ Tris- $\mathrm{HCl}, \mathrm{pH} 8.3$ at $4^{\circ} \mathrm{C}, 3 \mathrm{mM} \mathrm{NaN}_{3}$ and $10 \mathrm{mM} \mathrm{N}$ ethylmaleimide, containing $1 \%$ BSA. Approximately $100 \mathrm{ml}$ of 
cell-free human plasma was applied to a 1-ml immunosorbent column in a Pasteur pipette equipped above with a funnel (25 cm extension) and below with a narrow Teflon tube $(30 \mathrm{~cm})$ (Du Pont Co. Wilmington, Del.) to generate an operating pressure of $\cong 60 \mathrm{~cm}$ of water. The passage of the plasma usually required $\cong 10 \mathrm{~h}$. The column was washed with $30 \mathrm{ml}$ of equilibration buffer, $10 \mathrm{ml}$ of $1 \mathrm{M} \mathrm{NaCl}$ and $50 \mathrm{ml}$ of equilibration buffer free of BSA.

IRI material was eluted with $15 \mathrm{ml}$ of $1 \mathrm{M}$ acetic acid into a conical evaporating tube containing $100 \mu \mathrm{l}$ of equilibration buffer with $1 \%$ BSA. The sample was evaporated down to $1 \mathrm{ml}$ on a rotary evaporator (Evapo-mix, Buchler Instruments Div., Searle Diagnostic Inc., Fort Lee, N. J.). The column was regenerated by washing with two additional 15-ml portions of $1 \mathrm{M}$ acetic acid, 2 days apart. This was followed by $100 \mathrm{ml}$ of equilibration buffer free of BSA.

Gel filtration. To the IRI sample from the immunosorbent column in acetic acid $1 \mathrm{ml}$ of $1 \%$ BSA was added and the sample was chromatographed on a column of Sephadex G-50 superfine $(1.5 \times 88 \mathrm{~cm})$ using $1 \mathrm{M}$ acetic acid for elution and collecting fractions of $2.5 \mathrm{ml}$. A $50-\mu \mathrm{l}$ aliquot of each fraction was directly assayed for IRI, and $50 \mu \mathrm{l}$ of $1 \mathrm{~N} \mathrm{NaOH}$ was added to the assay to maintain a $\mathrm{pH}$ of 7.4. Peak IRI fractions were pooled and evaporated to dryness on a rotary evaporator.

Polyacrylamide disc gel electrophoresis. Dry samples of IRI from gel filtration, directly from the immunosorbent column or other samples, were solubilized overnight at $4^{\circ} \mathrm{C}$ in $200 \mu \mathrm{l}$ of disc gel application buffer: $N$-ethylmaleimide, $1 \mathrm{mM}$; EDTA, $1 \mathrm{mM}$; $\mathrm{NaN}_{3}, 1.5 \mathrm{mM}$; urea, $7 \mathrm{M}$; BSA, 0.25\%; pH 7.6. This $200 \mu \mathrm{l}$ sample was incorporated into a $5 \%$ sample gel of a pH 9.5 Ornstein-Davis disc gel (38). The $10 \%$ running gel was $20 \mathrm{~cm}$ and the $4 \%$ stacking gel $1.2 \mathrm{~cm}$ long. During electrophoresis the temperature of the lower buffer reservoir was $18^{\circ} \mathrm{C}$. Electrophoresis was terminated when the bromphenol blue band was $1 \mathrm{~cm}$ short of the end of the gel tube. Gels were extracted from the glass tubes, frozen, and then cut into about 90 slices of $2 \mathrm{~mm}$ with an automatic advance razor blade gel slicer (Joyce, Loebl and Co., Ltd. Gatesheadon-Tyne, England). Slices were extracted with $1 \mathrm{ml}$ of radioimmunoassay buffer at $4^{\circ} \mathrm{C}$ for 4 days. A fraction of the extract was used for insulin and for proinsulin radioimmunoassays. Recovery of IRI was $84 \pm 9 \%$. Control gels were devoid of IRI. Electrophoretic mobilities were expressed as mean $R_{f}$ values relative to bromphenol blue from at least three experiments, and had a 0.005 SD.

Isoelectric focusing. The sample of IRI material contained in $0.2-0.8 \mathrm{ml}$ of $0.1 \mathrm{M}$ Tris- $\mathrm{HCl}, \mathrm{pH} 7.4$, and $1 \%$ BSA was incorporated into a $13-\mathrm{cm}$ gel of $10 \%$ acrylamide, $0.6 \%$ $N, N^{\prime}$-methylenebisacrylamide, $4 \%(\mathrm{wt} / \mathrm{vol})$ ampholytes and 20 $\mathrm{mg} / \mathrm{l}$ riboflavin and was polymerized by fluorescent light. The ampholytes for $\mathrm{pH} \mathrm{4-7}$ gradients consisted of $0.5 \%$ Ampholine pH 5-7 and 1.5\% Bio-Lyte pH 4-6. For pH 5-8 gradients the Bio-Lyte component was substituted by one with a pH 6-8 range. Electrofocusing was carried out for $6 \mathrm{~h}$ in a disc gel electrophoresis apparatus (Hoefer Scientific Instruments, San Francisco, Calif.) using $0.01 \mathrm{M} \mathrm{H}_{3} \mathrm{PO}_{4}$ as anolyte and $0.02 \mathrm{M} \mathrm{NaOH}$ as catholyte. Electrofocusing gels were sliced and extracted identically to electrophoresis gels. The $\mathbf{p H}$ gradient was determined in gels run in parallel. The isoelectric points (pI) measured in $\mathrm{pH}$ units had a 0.06 SD. No component in control gels interfered with the insulin immunoassay.

Radioimmunoassays. Insulin immunoreactivity was quantitated by the radioimmunoassay of Yalow and Berson $(27,28)$. Electrophoretically pure porcine insulin was used as a standard. Standards were based on a molar extinction coefficient in $0.01 \mathrm{M} \mathrm{HCl}$ of $\epsilon_{M}{ }^{277 \mathrm{~nm}}=608$; (39). Except where mentioned, insulin immunoreactivities reported were not corrected for the differential immunoreactivity of various insulin derivatives.

Proinsulin radioimmunoassays were performed according to Kuzuya et al. (29). Electrophoretically pure human proinsulin isolated from human pancreas extracts and assayed by the insulin radioimmunoassay was used as standard.

Trypsinization. Proinsulin-size IRI material (2-20 ng) was trypsinized with $24 \mu \mathrm{g}$ of African lungfish trypsin in $0.5 \mathrm{ml}$ of $0.1 \mathrm{M}$ Tris- $\mathrm{HCl} \mathrm{pH} 8.0,0.05 \% \mathrm{NaN}_{3}$, and $0.2 \%$ gelatin at $37^{\circ} \mathrm{C}$ for $48 \mathrm{~h}$. The reaction was terminated by addition of $3 \mathrm{ml}$ of $3 \mathrm{M}$ acetic acid and the reaction mixture was characterized by gel filtration on Sephadex G-50 as described above. Crude soybean trypsin inhibitor $(30 \mu \mathrm{g})$ was added to each fraction to be radioimmunoassayed.

Characterization of reference proinsulin and insulin derivatives. The disc gel electrophoretic mobility at pH 9.5 for a number of pure proinsulin and insulin derivatives was determined. A typical experiment is shown in Fig. 2. $\boldsymbol{R}_{\boldsymbol{f}}$ values relative to bromphenol blue for all available porcine and human derivatives of known constitution were fitted by the method of least squares to the empirical relationship

$$
R_{f}=\mathrm{A} z^{\mathrm{B}} / M^{\mathrm{C}},
$$

wherein $A, B$, and $C$ are unknown empirical numbers, $M$ is the molecular weight and $z$ is the net negative charge of the insulin derivative at $\mathrm{pH} 9.5$, estimated from the amino acid sequence and typical $\mathrm{pK}_{\mathrm{a}}$ values of ionizable groups involved (Fig. 3), as explained in Fig. 1. Human insulin differs from porcine insulin only by having threonine in position 30 instead of alanine. Thus, no electrophoretic difference was observed between the two insulins. In contrast, the two proinsulins differ by 10 residues. In particular, human proinsulin is one charge more negative and two residues longer than the porcine homologue. Thus, $R_{f}$ values of human proinsulin derivatives were, in general, not identical to their porcine counterparts. Fig. 3 allowed prediction of the $R_{f}$ value of human proinsulin and insulin

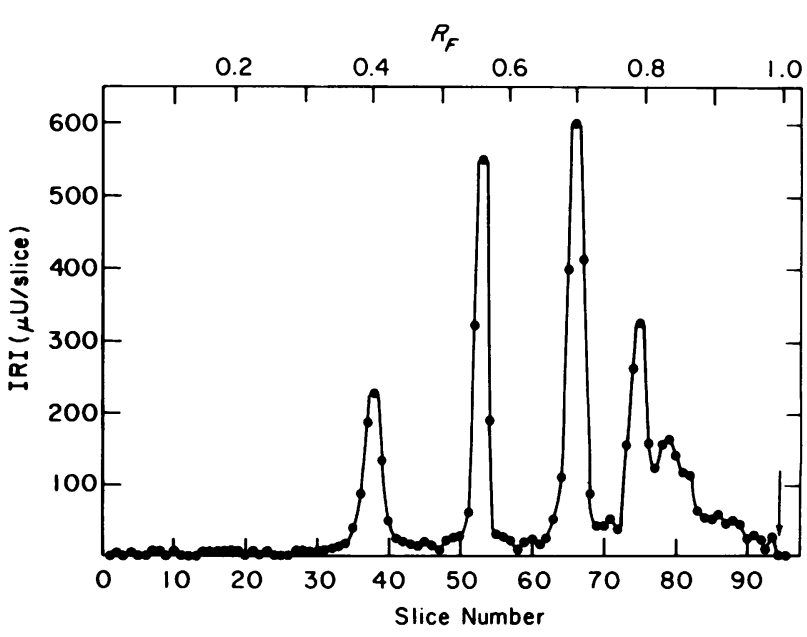

FIGURE 2 Disc gel electrophoresis of a mixture of porcine pancreatic derivatives of known chemical constitution. From left to right: diarginylinsulin, monoarginylinsulin, insulin, monodesamidoinsulin, desoctapeptide insulin. The arrow indicates the position of the tracking dye. Origin of standards and details of procedure are given in the text. 


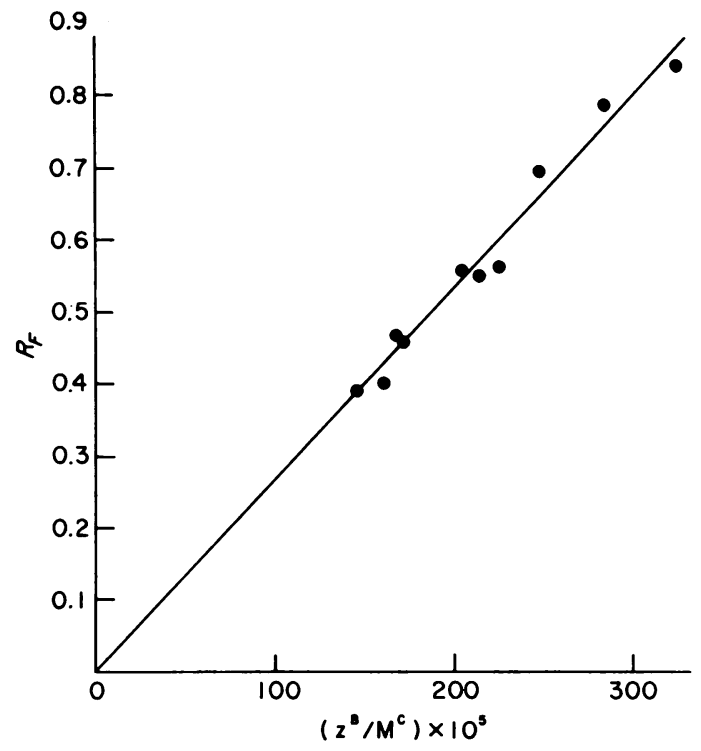

FIGURE 3 Semiempirical relationship between disc gel electrophoretic mobility relative to bromphenol blue $\left(\boldsymbol{R}_{f}\right)$, net electric charge $(z)$ and molecular weight $(M)$, according to $R_{f}=A z^{\mathrm{B}} / M^{\mathrm{C}}$ (Eq. 1). The molecular weight $M$ was obtained from the amino acid sequence and the net charge $z$ was estimated by counting individual charged residues as exemplified for proinsulin in Fig. 1, and relying on the $\mathrm{pK}_{\mathrm{a}}$ value for the amino groups given by Tanford and Epstein (41) (Table II). The coefficients A, B, and C were obtained by a least square fit of this equation to data on these porcine pancreatic standards. The best fit was obtained with $\mathrm{A}=242.6, \mathrm{~B}=0.6405$, and $\mathrm{C}=0.7786$. The data points indicate from left to right: porcine proinsulin, porcine diarginylinsulin, human proinsulin, porcine split proinsulin, porcine monoarginylinsulin, porcine desnonapeptide proinsulin, porcine desdipeptide proinsulin, porcine or human insulin, porcine monodesamidoinsulin, porcine desoctapeptide insulin. The conditions of electrophoresis are given in the text.

derivatives of known constitution, and was therefore used for the identification of unknown peaks on disc gels.

The isoelectric points of reference compounds were determined by isoelectric focusing in polyacrylamide gels. Isoelectric points of reference compounds were plotted as a function of the difference between cationic and anionic groups on the molecule (Fig. 4). Most of the insulin derivatives fell on a straight line (Fig. 4A). Desamidoinsulin as an exception is discussed below.

To rationalize observed pI values of standards, and for identification of unknown plasma components, pI values were interpreted in terms of the dissociation constants $\left(K_{a}\right)$ of ionizable groups on the molecules. The isoelectric point of a multivalent ampholyte is determined primarily by the two closest $\mathrm{pK}_{\mathrm{a}}$ values of ionizable groups on the ampholyte, $K_{n}$ and $K_{n+1}$, that bracket the pI. The pI is given by

$$
\mathrm{pI}=\left(\mathrm{pK}_{\mathrm{n}}+\mathrm{pK}_{\mathrm{n+1}}\right) / 2 \text {. }
$$

The subscript $n$ is equal to the maximum positive charge the ampholyte may assume, and the $\mathrm{pK}_{\mathrm{a}}$ values are counted in increasing order starting with the most acidic one (40). The equal spacing of $\mathrm{pI}$ values for insulin derivatives in Fig. 4A suggested that the $\mathrm{pK}_{\mathrm{a}}$ values that determine the $\mathrm{pI}$ were similarly spaced. Taking the $\mathrm{pK}_{\mathrm{a}}$ values to be the mean of two neighboring pI values appeared in this case to yield a good estimate. Attempts to refine these values by a more complete equation for the isoelectric point (40) did not yield significant changes.

Table II compares $\mathrm{pK}_{\mathrm{a}}$ values from titration studies (4143) and chemical modification studies (43) with our $\mathrm{pK}_{\mathrm{a}}$ values estimated from isoelectric points of a series of insulin derivatives. Since the total number of cationic groups on monoarginylinsulin is seven, its $\mathrm{pI}$ is between the $\mathrm{pK}_{\mathrm{a}}$ 's of the seventh and the eighth ionizable groups from the acid end point, i.e., between $\mathrm{pK}_{\mathrm{a}}$ 's of the two histidinyl residues. Our pI value for this compound ( $\mathrm{pI}=6.4$ ) was in good agreement with the mean $\mathrm{pK}_{\mathrm{a}}$ of 6.4 found by titration (41). Moreover, extrapolation of the straight line in Fig. 4A predicted a value of 7.5 for the mean $\mathrm{pK}_{\mathrm{a}}$ 's of the two $\alpha$-amino groups, a value identical with that obtained by titration (41) and only slightly deviating from that obtained by chemical modification studies, i.e., 7.4 (43).

Interpretation of the pI value of desamidoinsulin required special consideration. Slobin and Carpenter (26) have shown that asparagine 86 (= asparagine A21) undergoes deamidation much faster than the remaining asparaginyl and glutaminyl residues. This is presumably because of neighborhood catalysis by the $\alpha$-carboxylate. The same $\alpha$-carboxylate could cause the $\mathrm{pK}_{\mathrm{a}}$ of the $\beta$-carboxyl group of the newly formed aspartyl residue to be high, and therefore justified its placement at the upper end of the list of acidic residues in insulin (Table II). With Eq. 2 and the pK $_{\mathrm{a}}$ of the glutamyl residue with highest $\mathrm{pK}_{\mathrm{a}}$, a $\mathrm{pK}_{\mathrm{a}}$ of 5.4 was estimated for the $\beta$-carboxylate of aspartate 86 in desamidoinsulin. Table II thus

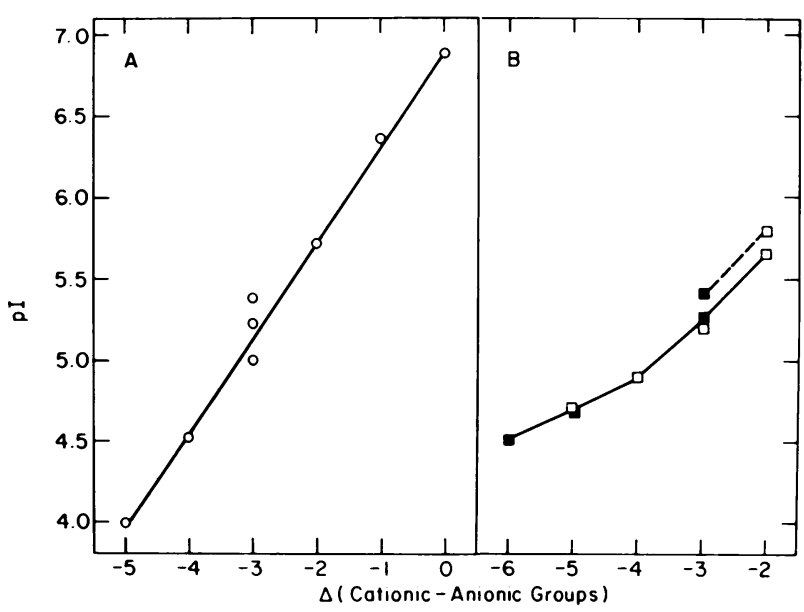

FIGURE 4 Isoelectric points of insulin and proinsulin derivatives as a function of the difference between the number of cationic and anionic ionizable groups on the molecule. (A) Porcine pancreatic insulin and derivatives of known chemical constitution. From left to right and low to high they are tribiotinyl-, dibiotinyl-, monobiotinyl-, desoctapeptide-, monodesamido-insulin, insulin, mono-, and diarginyl insulin. (B) Porcine pancreatic proinsulin and derivatives of known chemical constitution $(\square)$ and human counterparts (ם). The porcine standards from left to right and low to high are: monodesamido desdipeptide proinsulin, desdipeptide proinsulin, desnonapeptide proinsulin, split proinsulin, and proinsulin. The human compounds were identified by analogy as described in the text. The solid line links two-chain proinsulin derivatives, the interrupted line the intact proinsulins. 
TABLE II

$p K_{a}$ Values of Ionizable Groups of Insulin*

\begin{tabular}{|c|c|c|c|c|c|c|}
\hline $\mathrm{pK}_{\mathbf{q}}$ & Ionizable $g$ & & $\begin{array}{l}\text { Tanford and } \\
\text { Epstein (41) }\end{array}$ & $\begin{array}{l}\text { Gruen et al. } \\
\quad(42)\end{array}$ & $\begin{array}{l}\text { Kaplan and } \\
\text { Chan (43) }\end{array}$ & This work \\
\hline $\begin{array}{l}\mathrm{pK}_{1} \\
\mathrm{pK}_{2}\end{array}$ & $\begin{array}{c}\alpha-\mathrm{COOH} \\
\alpha-\mathrm{COOH}\end{array}$ & Asn, Ala (Thr) $\ddagger$ & $3.6 \S$ & & & \\
\hline $\mathrm{pK}_{3}$ & $\gamma-\mathrm{COOH}$ & Glu & & & & 3.9 \\
\hline $\mathrm{pK}_{4}$ & $\gamma-\mathrm{COOH}$ & Glu & 73 & & & 4.3 \\
\hline $\mathrm{pK}_{5}$ & $\gamma-\mathrm{COOH}$ & Glu & 4.73 & & & 4.8 \\
\hline $\mathrm{pK}_{6}$ & $\gamma-\mathrm{COOH}$ & Glu & & & & 5.4 \\
\hline $\mathrm{pK}_{7}$ & Imidazolyl & His & 6.40 & & 6.50 & 6.0 \\
\hline $\mathrm{pK}_{8}$ & Imidazolyl & His $\}$ & & & & 6.6 \\
\hline $\mathrm{pK}_{\mathbf{9}}$ & $\alpha-\mathrm{NH}_{2}$ & Phe & 745 & & 6.88 & 7.2 \\
\hline $\mathrm{pK}_{10}$ & $\alpha-\mathrm{NH}_{2}$ & Gly $\}$ & & & 7.89 & 7.7 \\
\hline $\mathrm{pK}_{11}$ & $\phi-\mathrm{OH}$ & Tyr & & & & \\
\hline $\mathbf{p K}_{12}$ & $\phi-\mathrm{OH}$ & Tyr & & & & \\
\hline $\mathrm{pK}_{13}$ & $\phi-\mathrm{OH}$ & Tyr & 9.60 & & & \\
\hline $\mathrm{pK}_{14}$ & $\phi-\mathrm{OH}$ & Tyr & & & & \\
\hline $\mathrm{pK}_{15}$ & $\epsilon-\mathrm{NH}_{2}$ & Lys & & 11.12 & 7.01 & \\
\hline $\mathrm{pK}_{16}$ & $-\mathrm{NH}-\mathrm{C}(=\mathrm{NH}) \mathrm{NH}_{2}$ & Arg & 11.9 & & & \\
\hline
\end{tabular}

* Porcine, bovine and human insulin are the same.

In human insulin threonine takes the position of alanine in porcine insulin position 30 .

$\$$ Mean values for the groups enclosed in the brackets.

explains rationally why the creation of an additional negative charge in desamidoinsulin is not equivalent in terms of pI to the loss of a positive charge (e.g., monobiotinylinsulin).

In contrast to the situation with insulin derivatives, $\mathrm{pI}$ values of proinsulin derivatives plotted as a function of the difference between cationic and anionic groups on the molecule did not yield a single straight line (Fig. 4B). Twochain proinsulin derivatives of porcine origin and, anticipating later identification, their human counterparts fell on a smooth curve. The two intact proinsulins lay slightly above that curve. This situation did not allow the pI values to be easily interpreted in terms of $\mathrm{pK}_{\mathrm{a}}$ values, as it was done for insulin derivatives above. Moreover, human compounds are more acidic than porcine products, due to the additional aspartic acid residue (position 36 ) in the C-peptide and would thus be expected to be offset by one toward the left in Fig. 4B. Human derivatives that fulfilled that expectation were indeed observed (Fig. 4B and Results).

\section{RESULTS}

Insulin levels. To allow extensive characterization of even minor components of human circulating IRI from individual donors, blood samples of $240 \mathrm{ml}$ were taken. Insulin levels were stimulated by oral glucose $(75 \mathrm{~g})$ followed by intravenous arginine $(30 \mathrm{~g})$ as described in Methods. In addition to yielding more IRI, the stimulated state was also more likely to show any insufficiencies or defects of proinsulin-to-insulin conversion. The plasma IRI levels ranged from 52 $\mu \mathrm{U} / \mathrm{ml}$ to $460 \mu \mathrm{U} / \mathrm{ml}$, yielding between 6,300 and $57,000 \mu \mathrm{U}$ of IRI for characterization.

Immunoextraction of human plasma. Plasma rather than serum was chosen for extraction of IRI to circumvent potential alterations of IRI components by the proteolytic enzymes of the coagulation system. For the same reason, coagulation was inhibited by a complex mixture of protease inhibitors (see Methods and Table I).

Human plasma IRI was extracted by an immunosorbent column (36) so as to separate it from large amounts of proteins, including proteases and their precursors. Elimination of excess protein was also required for disc gel electrophoresis and isoelectric focusing. Insulin antibodies were covalently coupled to agarose by cyanogen bromide (44), and to Affi-Gel 10 and $\mathrm{CH}-$ Sepharose 4B, two commercial affinity chromatography gels. All three affinity columns adsorbed porcine insulin and proinsulin quantitatively and gave good recoveries for insulin. Unexplainably only the last of the three gave good recoveries for proinsulin, and was thus used in this study. Human plasma IRI could be extracted quantitatively with this column, and apparent recoveries ranged from 80 to $100 \%$.

Identification of human IRI compounds. Human plasma IRI compounds eluted from the insulin immunosorbent column were first fractionated on Sephadex G-50 (Fig. 5). Proinsulin and insulin could be completely resolved as two peaks. Because porcine desoctapeptide insulin was not resolved from insulin on our column and no difference between porcine proinsulin and desnonapeptide proinsulin could be detected, we classified unknown human compounds into proinsulin- and insulin-like molecular size only. Fractions of insulin size material (elution volume/void volume $=1.94)$ were pooled, evaporated and sub- 


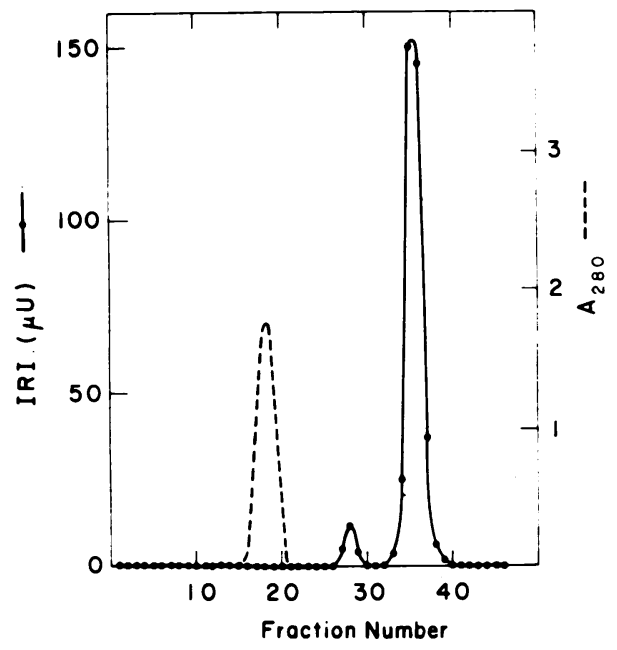

FIGURE 5 Gel filtration of insulin immunoextract of human plasma on Sephadex G-50 superfine $(1.5 \mathrm{~cm} \times 88 \mathrm{~cm})$ in $1 \mathrm{M}$ acetic acid. The flowrate was $15 \mathrm{ml} / \mathrm{h}$ and the fraction size $2.5 \mathrm{ml}$. The dotted line is bovine serum albumin.

jected to disc gel electrophoresis (Fig. 6A). $80 \%$ or more of the material migrated as a sharp peak with the mobility $\left(R_{f}=0.69\right)$ of authentic human or porcine insulin. A faster moving component formed a broad band covering the $R_{f}$ range expected for monodesamido- and desoctapeptide-insulin. Each of the two peaks was subjected individually to isoelectric focusing on polyacrylamide gels (Fig. 7A and B). Results from the large peak (Fig. 7A) showed that the major component was indeed insulin $(\mathrm{pI}=5.7$ ). It was however accompanied by variable amounts of material with $\mathrm{pI}$ values of 5.1, 5.6, 4.5, and 5.4 listed in order of decreasing relative size. Only the minor peak with $\mathrm{pI}=5.4$ was consistent with a previously identified natural product, i.e., monodesamidoinsulin. On the basis of Fig. 4, the two larger peaks ( $\mathrm{pI}=5.1$ and 4.5) appeared to carry one and two positive charges less than insulin, a difficult proposition. When the small electrophoretic peak material from Fig. 6A was subjected to isoelectric focusing (Fig. 7B), a similar pattern was observed as when large electrophoretic peak material from Fig. 6A was focused (Fig. 7A). The proportions of peaks differed, and the peak of insulin was much smaller. On refocusing of material from both the insulin peak $(\mathrm{pI}=5.7)$ and the $\mathrm{pI}=5.1$ peak similar patterns were obtained. This demonstrated that these peaks are in part interconvertible and thus artefactual, although we have been unsuccessful in identifying the nature of the artefact. Minor quantities of such products as deamidated insulin may have been present, but we concluded that the major part of the insulin-size material of Fig. 5 was insulin. Finally direct disc gel electropherograms of plasma immunoextract IRI of certain subjects showed peaks

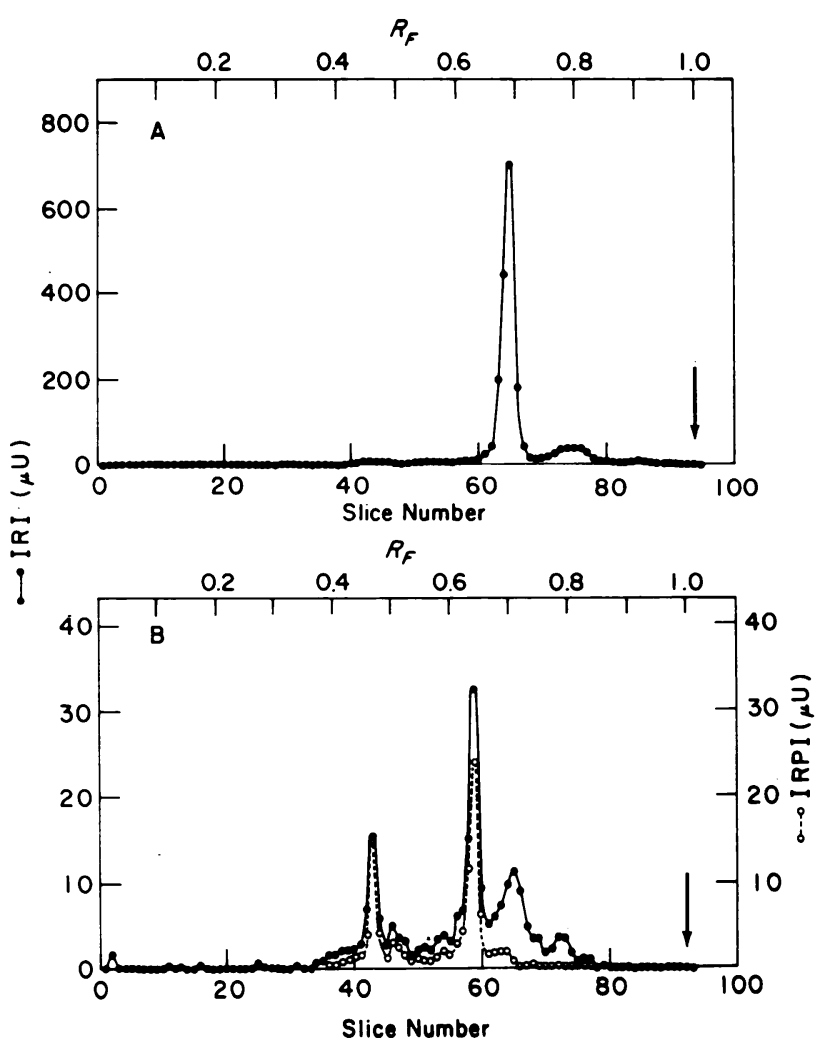

FIGURE 6 Disc gel electrophoresis of gel filtration fractions of human plasma IRI and immunoreactive proinsulin (IRPI). (A) Insulin-size material (fractions 33-38 of Fig. 5). (B) Proinsulin-size material (fractions 27-29 of Fig. 5). The arrow indicates the position of the tracking dye.

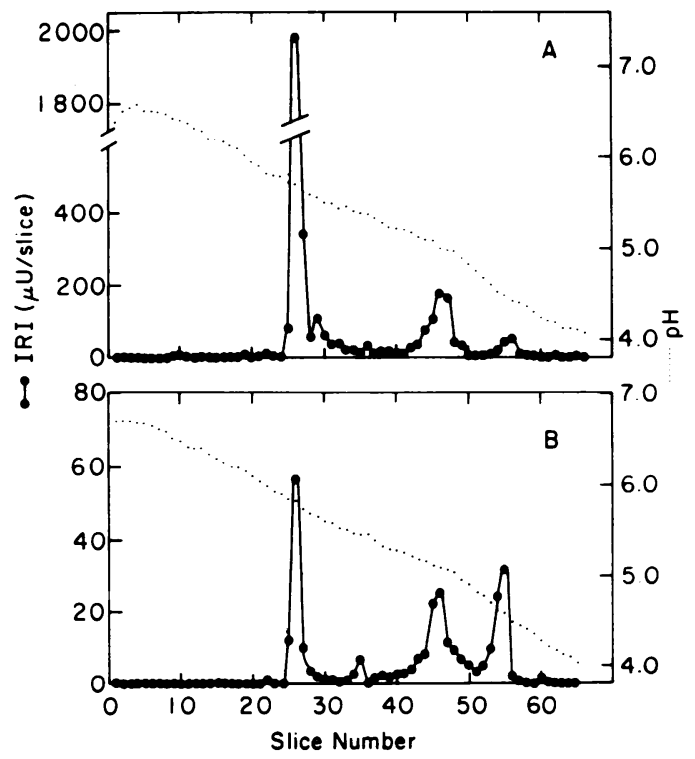

Figure 7 Isoelectric focusing gels of the two disc gel peaks of insulin-size material. (A) Material from insulin peak (major peak) of disc gel shown in Fig. 6A. (B) Material from minor peak of disc gel shown in Fig. 6A. 
in the position where diarginylinsulin runs, as well as other miscellaneous peaks (data not shown). None of these contained enough material to allow further characterization.

The proinsulin-size material from gel filtration (Fig. 5) (elution volume/void volume $=1.56$ ) was subjected to disc gel electrophoresis (Fig. 6B). The insulin immunoassay showed three major $\left(R_{f}=0.47,0.64\right.$, and $0.71)$ and a few minor peaks $\left(R_{f}=0.50,0.61\right.$, and 0.79). One of them $\left(R_{f}=0.71\right)$ had the mobility of insulin $\left(R_{f}=0.70\right)$. On gel filtration of this material most of the IRI was the size of insulin. We thus concluded that this electrophoretic peak was predominantly insulin contaminating our proinsulin-size matęrial. Two major peaks $\left(R_{f}=0.47\right.$ and 0.64$)$ and one minor peak $\left(R_{f}=0.50\right)$, observed in both the insulin and proinsulin radioimmunoassays, were further characterized. The peak with $R_{f}=0.47$ ran on electrophoresis where human proinsulin was predicted based on amino acid sequence and Fig. 3. The electrophoretic mobility and isoelectric points were identical with those of purified human pancreatic proinsulin. Upon trypsinization the material converted to insulin-size material. We therefore identified it as authentic human proinsulin.

The second major peak $\left(R_{f}=0.64\right)$ from disc gel electrophoresis (Fig. 6B) had the mobility predicted for desdipeptide proinsulin according to amino acid sequence and Fig. 3 (predicted $R_{f}=0.64$ ), and was distinct from that predicted for desnonapeptide proinsulin (predicted $R_{f}=0.62$ ). Isoelectric focusing of the same material showed a major peak with $\mathrm{pI}=4.7$, accompanied by a very small peak with $\mathrm{pI}=4.5$. Both peaks registered on the proinsulin assay. Trypsinization of the $\mathrm{pI}=4.7$ material yielded insulin-size material. The other peak contained too little material for this test. Assuming that the isoelectric points of human proinsulin derivatives would show a dependence on the difference between number of cationic and anionic groups parallel to their porcine counterparts (Fig. 4B), the pI $=4.7$ material had to be interpreted as human desdipeptide proinsulin accompanied by a small amount of the deamidated form with $\mathrm{pI}=4.5$.

On disc gel electrophoresis of proinsulin-size material from gel filtration, there was always present a minor peak with $R_{f}=0.50$ (Fig. 6B). Its mobility, reactivity with the proinsulin antibody and pI of 5.3 (Fig. 4B) identified it as split proinsulin. Finally there was a small peak with $R_{f}=0.61$. This material could be desnonapeptide proinsulin, although lack of sufficient amounts precluded further characterization.

Abbreviated characterization of human plasma IRI. In an attempt to provide a shorter method for characterizing human plasma IRI, which could also be per- formed with as little as $50 \mathrm{ml}$ of blood, immunoextracted plasma IRI was directly applied to disc gel electrophoresis. The plasma of six subjects was analyzed. A typical disc gel electrophoresis pattern of plasma IRI is shown in Fig. 8. Most of the immunoreactivity migrated as does authentic insulin $\left(R_{f}\right.$ $=0.70$ ). However, a number of minor components were present, that could constitute up to $15 \%$ of the total IRI. Invariably, there was a peak of material that had a slightly lower electrophoretic mobility than insulin and moved so close to insulin that it could be resolved only by disc gels of $20 \mathrm{~cm}$ length $\left(R_{f}=0.65\right)$. This component was identified as desdipeptide proinsulin as described above. Proinsulin $\left(R_{f}=0.48\right)$ was always present, but was often smaller than the desdipeptide peak. Sometimes there were additional minor peaks with lower mobilities than insulin, in particular split proinsulin $\left(R_{f}=0.55\right)$. The occasional appearance of a series of unresolved peaks with higher mobility than insulin, which we believe to be artefactual (see above) were also noted. Whereas, expectedly the total amount of insulin immunoreactivity varied considerably between individuals, the electrophoretic patterns of all subjects tested were essentially the same.

\section{DISCUSSION}

With an expanded set of techniques we have demonstrated that stimulated IRI in human plasma is heterogeneous not only in size (Fig. 5), but also in electrophoretic mobility (Fig. 6 and 8 ) and isoelectric point (Fig. 7). We demonstrated that the proinsulin-size fraction consisted of at least four constituents which we could partially identify. Ultimate identification would require isolation of sufficient material of each con-

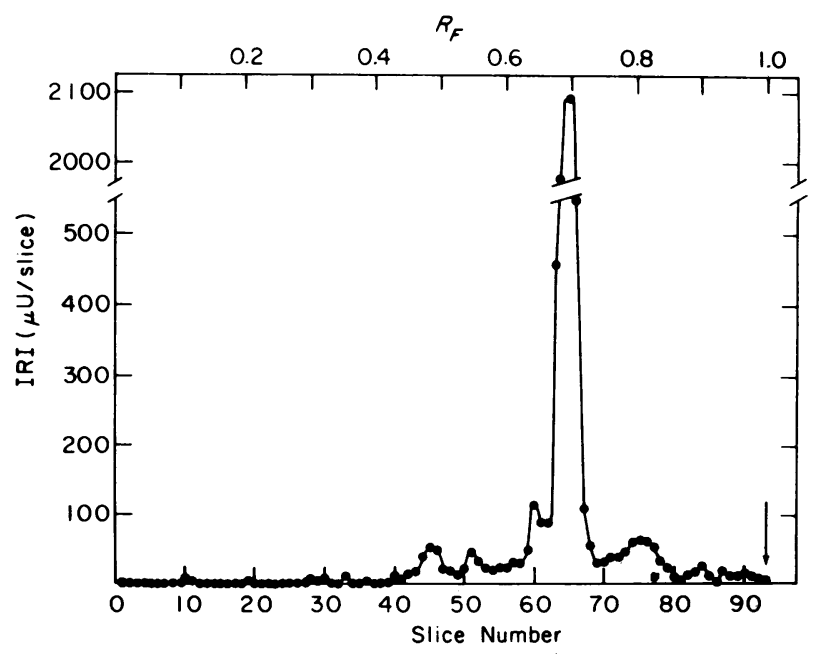

FIGURE 8 Disc gel electrophoresis of human plasma IRI. The arrow indicates the position of the tracking dye. 
stituent for amino acid analysis, which was presently not possible. The analytical resolution by disc gel electrophoresis for identification of plasma IRI was greatly improved over earlier work. Chemically characterized pancreatic insulin derivatives of porcine origin allowed the construction of a quantitative empirical relationship between amino acid composition (molecular weight and electric charge) and electrophoretic mobility (Fig. 3). This relationship served to predict the electrophoretic mobility of human analogues that had not previously been isolated.

It is important to realize that porcine proinsulin as well as desdipeptide- and desnonapeptide derivatives differ from their human counterparts by one negative charge (asparagine 36) at the $\mathrm{pH}$ of disc gel electrophoresis. For this reason porcine standards have electrophoretic mobilities different from their human analogues. Lazarus et al. (22) and Gutman et al. (23) reported data to show that the proinsulins from the two species move the same on disc gel electrophoresis, whereas Oyer et al. (5) showed that human proinsulin moves faster than bovine (and thus, also porcine) proinsulin. We also found such a difference. Moreover, the former authors report no separation of proinsulin from split proinsulin, again products differing by one charge, whereas we as well as Chance (14) found that the two components separated nicely. Finally, desdiand desnonapeptide proinsulin resolved poorly, because size difference compensated for charge difference (Fig. 3), whereas Lazarus et al. (21) reported dramatic separation. Although Lazarus et al. (21) and Gutman et al. (23) first demonstrated insulin immunoreactive material other than insulin and proinsulin in human circulation, and demonstrated that these compounds had biological activity, their identification remained tenuous.

In the present work IRI compounds identified by gel filtration, proinsulin radioimmunoassay, trypsin sensitivity, and disc gel electrophoresis were further characterized by isoelectric focusing. Porcine pancreatic standards as well as mono-, di-, and triacylated insulins (25) served to correlate isoelectric points to their chemical constitution, ultimately allowing partial identification of unknown components of human origin.

By this set of refined techniques we identified the following four compounds in the proinsulin-size fraction of human plasma IRI: proinsulin, split proinsulin, desdipeptide proinsulin, and a monodeamidated form of the latter. Intact proinsulin and desdipeptide proinsulin were predominant and in grossly comparable amounts. Split proinsulin and the deamidated desdipeptide proinsulin were present in lesser amounts. These statements about relative quantities have to be regarded with some reservation, because they are contingent on the validity of the assumption that human proinsulin compounds register on the insulin assay, using true insulin as a standard, in the same way as their porcine counterparts.

Our identification techniques did not distinguish [desdipeptide-(31-32), seco-30/33]-proinsulin from [desdipeptide-(64-65), seco-63/66]proinsulin. Although both species have been found in bovine pancreatic extracts $(11,45)$, the latter usually predominated, and in pig pancreas extracts thus far only [desdipeptide-64-65, seco-63/66]proinsulin has been found $(14,16)$. Plasma did not yield enough material for the amino acid analysis, required to distinguish between the twa possibilities.

What we identified as split proinsulin again could be any one or a mixture of the following products: [seco-32/33]-, [seco-65/66]-, [seco-54/55]- or [seco56/57]proinsulin. The first two would be the products of initial trypsin-like cleavage of proinsulin during conversion to insulin. Curiously these products have not been isolated from the pancreas yet, probably meaning that the subsequent removal of basic residues by carboxypeptidase B-like enzymes is very efficient. To a minor extent cleavage at $\mathrm{C}_{1}$ in Fig. 1 yielding [seco54/55]proinsulin appears to occur in the rat (46), whereas in the bovine cleavage at $\mathrm{C}_{2}$ (Fig. 1) yielding [seco-56/57]proinsulin seems to be preferred (13, 14). Human pancreas seems to contain (46) and secrete (29) a small amount of C-peptide fragment originating from a chymotryptic cleavage at $\mathrm{C}_{2}$ (Fig. 1). Although possibly present, the quantities of desnonapeptideproinsulin, the presumed precursor of the fragment, were insufficient for identification by isoelectric focusing. We suspect that chymotryptic cleavage is not an essential requirement for proinsulin activation, but is an inconsequential parallel occurrence.

In the insulin-size fraction of plasma IRI we found that true insulin constituted the predominant species. Some truly minor electrophoretic peaks in the position of diarginylinsulin and monodesamidoinsulin were occasionally observed.

It is currently thought that insulin is synthesized on the ribosome as preproinsulin, a molecule larger than proinsulin (48-51). Gorden et al. (52) have described material larger than proinsulin in a patient with islet cell carcinoma. Humbel et al. (53) and Nolan et al. (11) described proinsulin-size immunoreactive material that could not be converted to insulin-size material by trypsinization ("nonconvertible dimer"). In our subjects no such material was detected.

Melani et al. (54) succeeded in converting small amounts of proinsulin to insulin using bovine trypsin, while we could not consistently achieve this conversion. Prolonged digestion did not improve the results. Because we suspected autolysis, alteration of 
substrate specificity, and ultimate inactivation of bovine trypsin (55) to be the cause, we chose to use African lungfish trypsin, which is completely stable (30) to self-degradation.

The presence of significant amounts of desdipeptide and split proinsulin poses an interesting problem concerning the pathway of proinsulin-to-insulin conversion. There is little doubt that tryptic cleavage of proinsulin followed by carboxypeptidase B-like removal of carboxyterminal arginyl and lysyl residues is the predominant pathway. Thus, [desdipeptide-(64, 65), seco-63/66]proinsulin could well be an intermediate of the predominant pathway of proinsulin activation, as suggested by Kemmler et al. $(9,18)$. Alternatively, proinsulin could be predominantly activated by first splitting between residues 32 and 33 and only later splitting between residues 65 and 66 . In vitro experiments with pancreatic trypsin do not allow us to speak to this point. In the latter scenario, [desdipeptide- $(64,65)$, seco-63/66]proinsulin would represent the minor pathway intermediate that accumulates only because its further conversion is rate limiting. This may also set the stage for chymotryptic modification to desnonapeptide proinsulin, an intermediate observed in animal pancreas $(11,14,45)$ and inferred to be produced in humans as well $(29,46)$. A decision in favor of one of the two possible pathways will have to await further studies.

In summary, we have shown that human plasma IRI is more heterogeneous than previously recognized, and we have identified multiple components that are analogous to those isolated from animal pancreas. Finally, we have developed an approach that is suited to address the question of whether in certain forms of diabetes mellitus with normal IRI levels there are abnormal insulin species, or excessive amounts of proinsulin-insulin intermediates in circulation. Work in that direction is in progress.

\section{ACKNOWLEDGMENTS}

We thank Mrs. Marion Lance for dedicated assistance with the radioimmunoassays, for much of the time as a volunteer, Mrs. Sharon Kemp for typing the manuscript, and Dr. Jerry P. Palmer for assistance in early phases of this project. We thank Dr. Arthur H. Rubenstein for human proinsulin antibody, Dr. Ronald E. Chance for the characterized insulin derivatives, and Dr. David C. Teller for assistance with the nonlinear least square fitting.

This work was supported by grants AM 02456 and AM 05020 from the National Institutes of Arthritis and Metabolic Diseases. A portion of this work was conducted in the Clinical Research Center facility of the University of Washington, supported by the National Institutes of Health (grant RR-37) and through the Diabetes Center(AM 17047-03).

\section{REFERENCES}

1. Steiner, D. F., and P. E. Oyer. 1967. The biosynthesis of insulin and a probable precursor of insulin by a human islet cell adenoma. Proc. Natl. Acad. Sci. U. S. A. 57: 473-480.

2. Steiner, D. F., D. Cunningham, L. Spigelman, and B. Aten. 1967. Insulin biosynthesis: evidence for a precursor. Science (Wash. D. C.). 157: 697-700.

3. Clark, J. L., and D. F. Steiner. 1969. Insulin biosynthesis in the rat: demonstration of two proinsulins. Proc. Natl. Acad. Sci. U. S. A. 62: 278-285.

4. Chance, R. E., R. M. Ellis, and W. W. Bromer. 1968. Porcine proinsulin: characterization and amino acid sequence. Science (Wash. D. C.). 161: 165-167.

5. Oyer, P. E., S. Cho, J. D. Peterson, and D. F. Steiner. 1971. Studies on human proinsulin. Isolation and amino acid sequence of the human pancreatic C-peptide.J. Biol. Chem. 246: 1375-1386.

6. Ko, A. S. C., D. G. Smyth, J. Markussen, and F. Sundby. 1971. The amino acid sequence of the C-peptide of human proinsulin. Eur. J. Biochem. 20: 190-199.

7. Sorensen, R. L., M. W. Steffes, and A. W. Lindall. 1970. Subcellular localization of proinsulin to insulin conversion in isolated rat islets. Endocrinology. 86: 88-96.

8. Grant, P. T., and T. L. Coombs. 1970. Proinsulin, a biosynthetic precursor of insulin. In Essays in Biochemistry. P. N. Campbell and G. D. Greville, editors. Academic Press, Inc., Ltd. London. 6: 69-92.

9. Kemmler, W., D. F. Steiner, and J. Borg. 1973. Studies on the conversion of proinsulin to insulin. III. Studies in vitro with a crude secretion granule fraction isolated rat islets of Langerhans. J. Biol. Chem. 248: 4544-4551.

10. Steiner, D. F., O. Hallund, A. Rubenstein, S. Cho, and C. Bayliss. 1968. Isolation and properties of proinsulin, intermediate forms, and other minor components from crystalline bovine insulin. Diabetes. 17: 725-736.

11. Nolan, C., E. Margoliash, J. D. Peterson, and D. F. Steiner. 1971. The structure of bovine proinsulin. $J$. Biol. Chem. 246: 2780-2795.

12. Steiner, D. F., S. Cho, P. E. Oyer, S. Terris, J. D. Peterson, and A. H. Rubenstein. 1971. Isolation and characterization of proinsulin C-peptide from bovine pancreas. J. Biol. Chem. 246: 1365-1374.

13. Chance, R. E. 1970. Chemical, physical, biological and immunological studies on porcine proinsulin and related polypeptides. In Proc. VII Congr. Int. Diabetes Fed., Buenos Aires. Excerpta Medica International Congress Series, No 231. Excepta Medica, Amsterdam. 292-305.

14. Chance, R. E. 1971. Amino acid sequences of proinsulins and intermediates. Diabetes. 2(Suppl. 2): 461-467.

15. Yu, S. S., and A. E. Kitabchi, 1973. Biologic activity of proinsulin and related polypeptides in the fat tissue. J. Biol. Chem. 248: 3753-3761.

16. Chance, R. E., M. A. Root, and J. A. Galloway. 1976. The immunogenicity of insulin preparations. Acta Endocrinol. 83(Suppl. 205): 185-196.

17. Tager, H. S., and D. F. Steiner. 1972. Primary structure of the proinsulin connecting peptides of the rat and the horse. J. Biol. Chem. 247: 7936-7940.

18. Kemmler, W., J. D. Peterson, and D. F. Steiner. 1971 Studies on the conversion of proinsulin to insulin. I. Conversion in vitro with trypsin and carboxypeptidase B. J. Biol. Chem. 246: 6786-6791.

19. Roth, J., P. Gorden, and I. Pastan. 1968. "Big insulin": a new component of plasma insulin detected by immunoassay. Proc. Natl. Acad. Sci. U. S. A. 61: 138-145.

20. Rubenstein, A. H., S. Cho, and D. F. Steiner. 1968. Evidence for proinsulin in human urine and serum. Lancet. I: $1353-1355$.

21. Lazarus, N. R., R. A. Gutman, and L. Recant. 1971. A method for electrophoretic characterization on polyacryl- 
amide gel of circulating insulin immunoreactive substances. Anal. Biochem. 40: 241-246.

22. Lazarus, N. R., R. A. Gutman, J. C. Penhos, and L. Recant. 1972. Biologically active circulating proinsulinlike materials from an islet cell carcinoma patient. Diabetologia. 8: 131-135.

23. Gutman, R. A., N. R. Lazarus, and L. Recant. 1972. Electrophoretic characterization of circulating human proinsulin and insulin. Diabetologia. 8: 136-140.

24. Young, J. D., and F. H. Carpenter. 1961. Isolation and characterization of products formed by the action of trypsin on insulin. J. Biol. Chem. 236: 743-748.

25. May, J. M., R. H. Williams, and C. de Haën. 1978. $\mathrm{N}^{\epsilon, \mathrm{B} 29}-(+)$-Biotinylinsulin and its complexes with avidin. Synthesis and biological activity. J. Biol. Chem. 253: 686-690.

26. Slobin, L. I., and F. H. Carpenter. 1963. The labile amide in insulin: preparation of desalanine-desamido-insulin. Biochemistry. 2: 22-28.

27. Yalow, R. S., and S. A. Berson. 1960. Plasma insulin concentrations in nondiabetic and early diabetic subjects. Determinations by a new sensitive immuno-assay technique. Diabetes. 9: 254-260.

28. Yalow, R. S., and S. A. Berson. 1973. Non-pituitary hormones: radioimmunoassay. In Peptide Hormones. S. A. Berson, and R. S. Yalow, editors. North-Holland Publishing Co., Amsterdam Vol. 2B. 864-870.

29. Kuzuya, H., P. M. Blix, D. L. Horwitz, A. H. Rubenstein, D. F. Steiner, C. Binder, and O. K. Faber. 1977. Heterogeneity of circulating C-peptide. J. Clin. Endocrinol. Metab. 44: 952-962.

30. de Haën, C., K. A. Walsh, and H. Neurath. 1977. Isolation and amino-terminal sequence analysis of a new pancreatic trypsinogen of the African lungfish Protopterus aethiopicus. Biochemistry. 16: 4421-4425.

31. Fujikawa, K., M. E. Legaz, and E. W. Davie. 1972. Bovine factors $X_{1}$ and $X_{2}$ (Stuart factor). Isolation and characterization. Biochemistry. 11: 4882-4891.

32. Oshima, G., J. Kato, and E. G. Erdös. 1974. Subunits of human plasma carboxypeptidase $\mathrm{N}$ (Kininase I; anaphylatoxin inactivator). Biochim. Biophys. Acta. 365: 344-348.

33. Mäkinen, P-L., and J. Raekallio. 1974. Aminopeptidases in the serum of pregnant and nonpregnant women. Biochem. Med. 11: 210-216.

34. Meloun, B., L. Moravek, and V. Kostka. 1975. Complete amino acid sequence of human serum albumin. FEBS (Fed. Eur. Biochem. Soc.) Lett. 58: 134-137.

35. Svedson, A., and J. Carlsson. 1975. The thiol groups of bovine serum albumin. High reactivity at acidic $\mathrm{pH}$ as measured by the reaction with 2,2'-dipyridyldisulfide. Biochim. Biophys. Acta. 400: 433-438.

36. Akanuma, Y., T. Kuzuya, M. Hayashi, T. Ide, and N. Kuzuya. 1970. Immunological reactivity of insulin to sepharose coupled insulin-antibody - its use for the extraction of insulin from serum. Biochem. Biophys. Res. Commun. 38: 947-953.

37. Miles, L. E. M., and C. N. Hales. 1968. The preparation and properties of purified ${ }^{125}$ I-labeled antibodies to insulin. Biochem. J. 108: 611-618.

38. Davis, B. J. 1964. Disc electrophoresis. II. Method and application to human serum proteins. Ann. N. Y. Acad. Sci. 121: 404-427.

39. Hamlin, J. L., and E. R. Arquilla. 1974. Monoiodoinsulin. Preparation, purification and characterization of a biologically active derivative substituted predominantly on tyrosine A14. J. Biol. Chem. 249: 21-32.

40. Hitchcock, D. I. 1936. Calculation of isoelectric zones and isoelectric points. J. Biol. Chem. 114: 373-379.

41. Tanford, C., and J. Epstein. 1954. Physical chemistry of insulin. I. Hydrogen ion titration curve of zincfree insulin. J. Am. Chem. Soc. 76: 2163-2169.

42. Gruen, L., M. Laskowski, Jr., and H. A. Scheraga. 1953. Thermodynamics of the ionization of the lysyl residue of insulin. J. Am. Chem. Soc. 81: 3891-3901.

43. Kaplan, H., and Y. K. Chan. 1977. Ionization constants and reactivities of functional groups in insulin. Fed. Proc. 36: 668. (Abstr. 2089.)

44. Cuatrecasas, P. 1970. Protein purification by affinity chromatography. Derivatization of agarose and polyacrylamide beads. J. Biol. Chem. 245: 3059-3065.

45. Markussen, J., and L. G. Heding. 1976. Separation of the two double-chain bovine intermediates of the proinsulininsulin conversion. I. Chemical, immunochemical, circular dichroism, and biological characterization. Int. J. Pept. Protein Res. 8: 597-606.

46. Heding, L. G., V. D. Larsen, J. Markussen, K. H. Jørgensen and $O$. Hallund. 1974. Radioimmunoassays for human, pork and ox C-peptides and related substances. Horm. Metab. Res. 5(Suppl.): 40.

47. Tager, H. S., S. O. Emdin, J. L. Clark, and D. F. Steiner. 1973. Studies on the conversion of proinsulin to insulin. II. Evidence for a chymotrypsin-like cleavage in the connecting peptide region of insulin precursors in the rat. J. Biol. Chem. 248: 3476-3482.

48. Yip, C. C., C. L. Hew, and H. Hsu. 1975. Translation of messenger ribonucleic acid from isolated pancreatic islets and human insulinomas. Proc. Natl. Acad. Sci. U. S. A. 72: 4777-4779.

49. Chan, S. J., P. Keim, and D. F. Steiner. 1976. Cellfree synthesis of rat preproinsulins: characterization and partial amino acid sequence determination. Proc. Natl. Acad. Sci. U. S. A. 73: 1964-1968.

50. Lomedico, P. T., and G. F. Saunders. 1976. Preparation of pancreatic mRNA: cell-free translation of an insulinimmunoreactive polypeptide. Nucleic Acid Res. 3: 381386.

51. Permutt, M. A., J. Biesbroeck, R. Chyn, I. Boime, E. Szczesna, and D. McWilliams. 1976. Isolation of a biologically active messenger RNA: preparation from fish pancreatic islets by oligo(2'-deoxy-thymidilic acid) affinity chromatography. In Polypeptide Hormones: Molecular and Cellular Aspects. Ciba Foundation Symposium no. 41. Elsevier Scientific Publishing Co., Amsterdam, 97-116.

52. Gorden, P., B. Sherman, and J. Roth. 1971. Proinsulinlike components of circulating insulin in the basal state and in patients and hamsters with islet cell tumors.J. Clin. Invest. 50: 2113-2122.

53. Humbel, R. E., H. Bünzli, K. Mülly, O. Oelz, E. R. Froesch, and W. J. Ritschard. 1970. Insulin-like substances: the insulin dimers and non-suppressible insulinlike activity. In Proc. VII Congr. Internat. Diabetes Fed. Buenos Aires, Excerpta Medical International Congress Series No. 231. Amsterdam. 306-317.

54. Melani, F., A. H. Rubenstein, and D. F. Steiner. 1970. Human serum proinsulin. J. Clin. Invest. 49: 497-507.

55. Keil-Dlouhá, V., N. Zylber, J-M. Imhoff, N-T. Tong, and B. Keil. 1971. Proteolytic activity of pseudotrypsin. FEBS (Fed. Eur. Biochem. Soc.) Lett. 16: 291-295. 